\title{
A German Lawyer in the Far East: Investing and Doing Business in China
}

\author{
Stefan Messmann*
}

\begin{abstract}
Shortly after the end of the Cultural Revolution, some four decades ago, there were no passenger cars in China when Volkswagen AG started its negotiations inthis country. The country was poor and underdeveloped. Today, the GDP of China reached USD 17.6 billion compared to the US' 17.4 billion USD. Car production in China is now more than 18 million cars per year, more than in the USA. Today, China is still a socialist country and its economic system is called 'socialist market economy' but there are about 50 million private companies, 400 million people are belonging to the middle class and there are about 800 super rich having more than 100 million USD on average. In this 'sino-marxist' country, there are even 130 multi billionaires in USD. No wonder that under these circumstances, joint ventures and wholly foreign-owned enterprises, especially also in the automotive industry, are welcome.

Volkswagen started its negotiations with its Chinese partner, STAC (Shanghai Tractor and Automobile Investment Corporation), BoC (Bank of China) and CNAIC (China National Automotive Industry Corporation) in 1979. These negotiations ended in 1984 by setting up the 'Shanghai-Volkswagen' joint venture which started the production of the Santana in 1985. Some years later, in 1988, Volkswagen started the negotiations with FAW (First Automobile Work) in Changchun. These negotiations lasted much shorter and the second VW joint venture, 'FAWVW', started with the production of Jetta and Audi 100, 100, 000 cars per year in 1991.In 2004, the 'Volkswagen Group China' (VGC), a wholly VW-owned holding company was set up in Beijing in order to coordinate the VWparticipations, the sales and marketing of its joint ventures, the purchasing, personnel and governmental relations as well as finance. Today, VGC has, including its 16 subsidiaries, 95,000 employees, has built 30 million cars at 30 Chinese production sites and sold them by 5,000 dealers (with 330,000 employees). In 2016, VGC has built about 4 million cars.
\end{abstract}

Keywords: Volkswagen (VW), joint venture, wholly foreign-owned company, socialist market economy, sinomarxism, Shanghai Automotive Industry Company (SAIC), Shanghai-Volkswagen (SVW), First Automobile Work (FAW), Volkswagen Group China (VGC)

\section{INTRODUCTION}

The title of this paper, a least the 'A German lawyer...' part, needs an explanation. The Author is a German citizen and has worked in the Foreign Legal Department of Volkswagen AG in Wolfsburg/Germany but he studied Swiss law in French in Geneva; was an attorney in Shanghai and taught International Business Law at the Central European University (CEU) in English in Budapest/Hungary. None of the Author's activities in Volkswagen AG's Foreign Legal Department were concerned with German law but his point of view will be that of a German lawyer as his experiences in investing and doing business in China will be presented from a former Volkswagen lawyer and Deputy General Manager of Shanghai Volkswagen perspective.

* Dr. iur., former Professor of International Business Law in the Legal Studies Department of Central European University in Budapest/Hungary, e-mail: stefanmessmann@outlook.com. This thematic issue (Missed and new opportunities in world trade. Eds. Csongor István Nagy \& Zoltán Víg) was published as part of the research project of the HAS-Szeged Federal Markets 'Momentum' Research Group. 


\section{BIG CHANGES}

Shortly after the end of the Cultural Revolution, some four decades ago, there were no passenger cars in China when Volkswagen AG started its negotiations in this country.

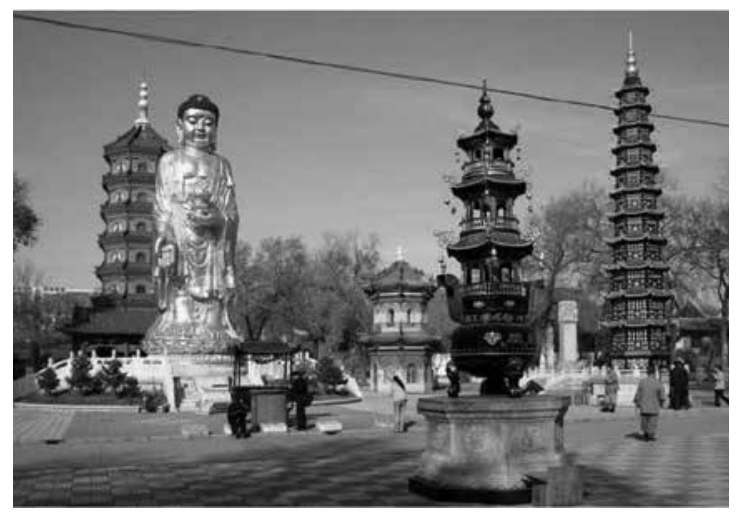

Today, on the other hand, there is almost no space in this country without cars.

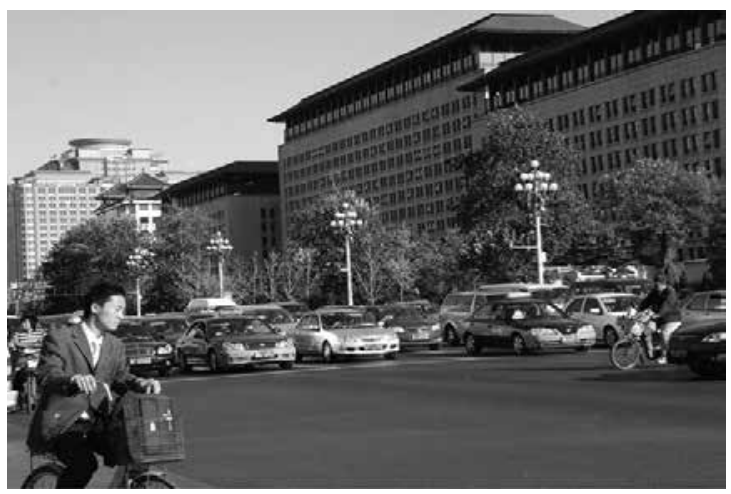

In order to explain this big change, and the enormous contribution of Volkswagen AG(VWAG) to this change, the Author will deal first with the actual situation in China, thereafter with its economic and political system, thirdly, with its higher education, which made a large contribution to the economic development of China, fourthly, with the development of the Chinese law, which made possible foreign direct investments (FDI), before entering, finally, in detail to VWAG investment and doing business in this country.

\section{CHINA TODAY}

China has today a population of 1.388 billion people. ${ }^{1}$ Shanghai, the city of the first joint venture of VWAG in China, has 24.15 million people ${ }^{2}$ and is the largest city of this country. Changchun, the capital of Jilin province, the city of the second joint venture of VWAG, has a population of 3.815 million. ${ }^{3}$

1 China Population (2017) link 1.

2 Shanghai Population (2017) link 2.

3 Changchun Population (2010) link 3 
In 1978, shortly after the Cultural Revolution (1966-1976), only $18 \%$ of the Chinese population lived in cities. Today, $51 \%$ of the Chinese, i.e., about 700 million, are living in cities which also means a large increase of social wealth. ${ }^{4}$ In the next 20 years, an additional hundreds of millions of Chinese may also move to cities. ${ }^{5}$ Today, China is the second biggest economic power in the world, after the USA, with the potential to overtake the USA in the next decades, among others according to such experts like Zbigniew Brzezinski. ${ }^{6}$ Already in 2014, the Chinese GDP reached USD 17.6 million compared with the USD 17.4 million of the USA and it is expected that in 2050 the Chinese GDP will reach USD 61.1 billion against the USD 42.2 billion by the USA. ${ }^{7}$ It is no wonder, therefore, that China is attracting more foreign investors. In 2016, the FDI to China was USD 118 billion $^{8}$ after USD 10 billion only in 1990 and USD 60 billion in 2000. This FDI went mostly to industry, technology (IT) and leasing sectors but Chinese companies have also started to invest more abroad. Thus, in 2016, FDI from China reached USD 61 billion. ${ }^{9}$ Chinese companies, private and state ones, are making frequently purchase tours in the USA and in the EU countries to buy enterprises which have important know-how, necessary for the further development of the Chinese industry e.g., last year, Chinese firms closed overseas deals worth USD 61 billion. This was up by $16 \%$ on 2014 and is the highest level on record. ${ }^{10}$

The most FD to China came from Hong Kong and Taiwan and from the EU countries like France, Germany and the UK and predominantly went to Guangdong, Shanghai and Jiangsu. ${ }^{11}$

China is also actually the largest trade partner of the EU and the USA with a trade volume of USD 560 billion in 2016 and thus exports more than the USA and Germany together. ${ }^{12}$ It is no wonder that as a result of this fast economic development, China's foreign currency reserves amount to USD 3,000 billion ${ }^{13}$ and the Renminbi is today in the basket of currencies of the International Monetary Fund (IMF). ${ }^{14}$

\section{CHINESE ECONOMIC AND POLITICAL SYSTEM}

China is still a socialist country but its economic system is called a 'socialist market economy'. However, it does not mean that the Chinese economy is a state economy, like other former socialist countries and China before 1978. When Chairman Mao Zedong died in 1976, the average income per person was USD 250 per year but it is now 30 times higher. ${ }^{15}$ As a result of this development, there are today about 50 million private companies in China, among them such well-known companies like Vanke, Geely, and Alibaba, accounts for about $80 \%$ of the Chinese companies producing about $60-70 \%$ of the country's GDP.

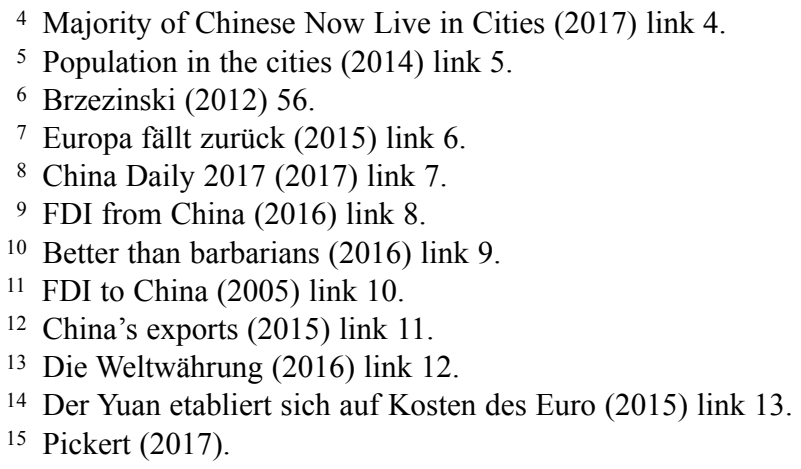


About 4,000 new private companies are registered daily in this country though the State's influence on the economy remains high.

The result of such economic development is that there is today about 400 million people belonging to the middle class and about 800 super rich having more than 100 million USD in average and there are even 130 multi billionaires in USD including several women. The richest Chinese is Wang Jianlin, whose father fought under Chairman Mao Zedong, owns a fortune of USD 34 billion. ${ }^{16}$ Belonging to the middle class means having an apartment or a house and, of course, a car. In 2016, about 120 million Chinese went abroad as tourists and about 900 million have a mobilephone. It is no wonder that, under these circumstances, the Chinese Communist Party (CCP) is sometimes called 'Chinese Capitalist Party' by some Western observers.

The long term strategic aim for Chinese companies is to buy more foreign enterprises, especially in the USA and Germany, in order to enhance their technology but are also interested in airports and consumer goods. ${ }^{17}$

Higher education in China also contributed to this fast economic development. There are today 25 million students in higher education in this country, among them 73,000 $\mathrm{PhD}$ students in technical subjects, while between 1981 and 2001 there were 'only' 51,000 students in technical subjects. It is also of great importance for China that there are 140,000 Chinese students studying in the USA alone and the common experience, upto now, is that $80 \%$ of theses Chinese students studying abroad will return home.

The Chinese political system is generally considered as a 'one party system' though there are eight political parties in the People's Congress, twice as many as in the Hungarian Parliament. The electoral system is also developing, though it is often ignored in the Western countries. For example, on the country level, there is no limitation to the number of candidates for local elections and they must not be necessarily members of the CCP.

The official political system in the PRC in the post-Mao period is often considered by Western China-researchers as 'pragmatic', 'post-Maoist', or 'capitalist' and according to them, 'Maoism' has been replaced by Deng Xiaoping's pragmatism. They refer to a CCP 'Resolution about some questions in our Party history since the founding of the CCP' of 1981 , which pointed out the 'grave mistakes' made by Mao Zedong in his 'late years'. The CCP, however, continues to uphold the 'Mao Zedong Thought', except for a few ideas propagated by Mao Zedong during the Cultural Revolution. The 'Mao Zedong Thought' is, however, only a part of the CCP's 'guide to action'. The CCP 'takes Marxism-Leninism, Mao Zedong Thought, Deng Xiaoping Theory, The important thought of Three Represents and the Scientific Outlook on Development as its guide to action'. Therefore, an adequate name for the whole system of this 'guide to action', for the actual Chinese political system is 'Sinomarxism'. 18

\section{DEVELOPMENT OF CHINESE LAW}

The origin of Chinese law dates back to a time many centuries before the beginning of the Christian era and had two fundamental characteristics: Legist and Confucian, consisting in 'the tradition of promulgating dynastic codes and a steady adherence to a set of underlying

16 Der reichste Chinese (2015) link 14.

17 Chinesen kaufen (2016) link 15.

18 Von Senger and Senn (2014). 
principles based on the Confucianist world outlook'. ${ }^{19}$ At that time, there was no concept of independent judiciary as the local mandarins acted as judges but a special board, called Tingwei or Dalisi, acted as the highest court of appeal. ${ }^{20}$

Modernisation started after the Boxer Uprising of 1900 and this including legal reform. In 1906, the first Western-style law school was opened in Beijing and after the Revolution of 1911, the modernization of the law continued and German law seemed to be especially attractive to the new Chinese leadership, because of the military force of Germany at that time.

After Mao Zedong took power in 1949, the Soviet influence also become predominant in the Chinese legislation. It was followed by total lawlessness during the Cultural Revolution (1966-1976). ${ }^{21}$ After Mao's death in 1976, a new period started in China, also concerning the development of law.

The most important laws, from the economic point of view, after the Cultural Revolution were the Law on Joint Ventures using Chinese and Foreign Investment (1978); the Law on Foreign-Capital Enterprises (1986); the Law on Sino-foreign Cooperative Joint Ventures (1988); the Law on Establishment of Holding Companies by Foreign Business Entities (2004); the Company Law (revised in 2013) and the Economic Contract Law (1981) as well as the Foreign Economic Contract Law (1985).

These laws made it possible to set up joint ventures and wholly foreign-owned companies, including holding companies, subject, of course, to State approval. The participation ratio for foreign partners in joint ventures is minimum $25 \%$ and maximum $95 \%$ and for local partners minimum 5\%. In the joint ventures, contribution in technology is compulsory for the foreign partner but it is limited to $20 \%$ of the foreign invested capital. The joint venture law foresees some limitations in establishing joint ventures, such as the violation of the Chinese sovereignty, of Chinese laws and of the environment, obvious inequality in the contract as well as hindering of the Chinese economy.

For joint ventures and wholly foreign-owned companies, the Special Economic Zones are of special importance because of their export orientation and tax advantages.

\section{THE FIRST JOINT VENTURE OF VOLKSWAGEN: SHANGHAI-VOLKSWAGEN - NEGOTIATIONS AND ESTABLISHMENT}

After the 'open door policy' of Deng Xiaoping in 1978, the Chinese Ministry of Machine Building invited several foreign car manufacturers, among them Toyota, General Motors, Renault and VWAG, to negotiate the setting up of a joint venture in China for car production. Toyota, General Motors and Renault, after a short period of negotiations, did not show any interest to set up a joint venture in China estimating that if China will get their know-how, it will continue to build and sell their own cars, even abroad. Only VWAG had a different appreciation of the situation. Therefore, in 1978, a delegation of VWAG went to Beijing to get more detailed information about the intention of the Ministry of Machine Building. The Chinese part announced its intention to build 150,000 cars per year but VWAG first refused this proposal for reasons of high costs. Shortly thereafter, however, Dr. C. H. Hahn, the new CEO of VWAG, was very interested in this project and decided to immediately resume negotiations with the Chinese partners.

19 Ladány (1994) 35.

20 Ladány (1994) 36.

${ }^{21}$ Ladány (1994) 52. 
VWAG resumed the negotiations with Shanghai Tractor and Automobile Investment Corporation(STAC), a state-owned company, as early as in spring 1979, only a few months after the enactment of the Chinese joint venture law. Later on, the Bank of China (BOC) and the China National Automotive Industry Corporation (CNAIC) joined the negotiations, CNAIC mainly in order to supervise the negotiation on State level and BOC in order to guaranty the payment of dividends to VWAG. a Trial Manufacturing Agreement was signed on April 11, 1983 as the result of these new negotiations.

At that time, the negotiation with Chinese partners were not easy as the Chinese partners, after a long isolation, were not accustomed to negotiating with foreign partners; they were traditionally suspicious about the foreign partners' sincerity and willingness to transfer the most modern technology and update them at the same time as in the home country. Only a few members of the Chinese team could speak a foreign language and the head of the Chinese team was obliged to frequently report to the authorities, at the local and national level. This, of course, delayed the negotiations. The Chinese negotiation team was generally large, frequently consisting of 10-15 or more members, mostly engineers, a few businessmen and/or accountants and often no lawyers while the VWAG negotiation team generally consisted of a team leader, an engineer, a financial expert and a lawyer. The foreign and Chinese approaches in negotiations often appeared incompatible and as a result, foreigners usually see Chinese negotiators as inefficient, indirect, and even dishonest, while Chinese see foreign negotiators as aggressive, impersonal, and excitable.

Such differences have deep cultural roots. In negotiations, the Chinese business people usually adopt different intellectual games like, e.g., wei qi as well as other negotiation elements, like zhengti guannian. Wei qi is a game originated in the Zhu Dynasty (1046-256 $\mathrm{BC}$ ) which is played on a grid of black lines (usually 19x19). The objective of the game is to use one's stones to surround a larger total area of the board than the opponent. The Chinese zhengti guannian (holistic thinking) is completely different from the Western type of sequential and individualistic thinking, breaking up complex negotiation tasks into a series of smaller issues, such as price, quality, delivery, have given rise to a clearly defined set of elements that underpins the Chinese negotiation style. ${ }^{22}$

This set of elements is:

- zhengti guannian (holistic thinking)

- shehui dengji (social status)

- mianzi ('Face' or social capital)

- zhongjian ren (the intermediary used to influence the foreign partner)

- guanxi (personal connection)

- jiejian (thrift)

- chiku nailao (endurance, relentlessness, or eating bitterness and enduring labor)

- renji hexie (interpersonal harmony) ${ }^{23}$

In negotiations, Chinese partners largely use Sun Zi's theory on art of war. The ancient guidance of Sun Zi means that the wisest posture in combat is to lay back, let one's opponent make fatal mistakes and, only then, capitalise on them. The Chinese negotiating style may be characterized by

- opening moves

- period of assessment

22 Fernandez and Underwood (2009) 183.

23 Graham and Lam (2003). 
- end game

- implementation

The Author's personal experience is that is an opening move characteristic of Chinese partners is that they are quite reluctant to negotiate with lawyers and often even in presence of lawyers, probably because lawyers do not have the same reputation in China (shenhui dengji or social status) ${ }^{24}$ as in Europe and the USA. However, this situation may have changed by now. The Chinese team, consisting of technicians, businessmen and, sometimes, officials, tried to write a legal text with non-binding statements and vague formulations, while refusing verbatim every pronouncement made by the Western partner. This text is then presented it years later, when the circumstances have changed, and insisted that it represented a binding promise.

The tricks employed by the Chinese negotiators do not seem any different from those employed worldwide, they have however been refined to a ritual. Also, a ritualized negotiating process can be entrusted to middle-ranking managers and watched and directed discretely by those in real authority who do not wish to show their hand. In this way, those in the leadership can grant last minute concession to save negotiations from failure, or withhold their approval - without losing face.

One of the most important tasks of the Chinese negotiators in the opening phase of the talks is the search for the 'right partner' (zhongjian ren - intermediary) among the negotiators in the foreign team. This will not necessarily be the most senior of the foreign negotiators, but the one who seems to be forthcoming to the Chinese side. If they find a member of the foreign delegation who is willing to talk to them and to his colleagues outside of the formal negotiations, and appears to be helpful in putting across their point of view, they will shower him with attention and friendliness (renji hexie - personal harmony). The Chinese are great cultivators of friendly feelings as they believes that friendship results in obligations. Therefore, they look for a suitable person to act as a 'right' intermediary (guanxi - personal connection) between the two delegations. ${ }^{25}$

The place of negotiations also plays an important role in negotiations with Chinese partners. The negotiations rarely could take place abroad because the need for the Chinese negotiators to constantly refer to their superiors and also because of jiejian (thrift). China's history of economic and political instability has namely taught its people to save money. In addition, those who have real authority may not like the contract resulting from negotiations abroad which they were not able to follow and direct on a day-to-day basis.

The Chinese location for the talks is particularly important for the second phase (period of assessment) where the foreign team is asked to present its ideas in more details. Such ideas are immediately communicated to the invisible persons of authority. They will then decide the line to be adopted by the Chinese negotiators, reaching their decisions based on reports from their negotiators, without discussion with the foreign party. After the main line to be taken has been determined by those in authority, the Chinese technique did not seem to be particularly original:

- the usual attempt off play out members of the foreign team against each other, the labeling of its individual members as 'good' or 'bad',

- attempts to make the foreign partner feel guilty about delays when opposing unacceptable demands,

- attempts to exert pressure through the press and media,

24 Chapel (1998) 172.

25 Graham and Lam (2004) 43. 
It may happen that the Chinese negotiators will be so 'good' at the delaying tactics designed to tire out the foreigner that they will put themselves under time pressure and as result , they suddenly forgot about all-important principles and essential details in the rush to be able to submit the signed contract for approval as soon as possible.

In such a case, the essential details will be left out in the hurry but will come back with a vengeance and negotiations will be reopened after signatures.

In the VWAG case, the conclusion of the agreement (end of the game) was not yet the beginning of business as our contract was subject to approval by the appropriate authority. Only after the approval had been obtained, could the assembly of cars and production of engines could start (implementation).

It is no wonder that the negotiations between VWAG and STAC, and later on with the participation of BOC and CNAIC as further partners, lasted for five years. The reasons are multiple and the difficulties in negotiation with Chinese partners has already been mentioned but in addition, there were also some political reasons. Chen Yun, then one of the most influential leaders of China, was also responsible for approval of foreign investments, intentionally delayed the approval of this contract, as reported by the former Chinese Prime Minister, Zhao Ziyang. ${ }^{26}$ The leader of the VWAG negotiating team, Heinz Bauer, noticed that for these negotiations, 29 negotiation rounds of three weeks were needed, nine travels to China spending there 230 days there altogether, additionally, of course, to the negotiations in Wolfsburg. ${ }^{27}$

This Joint Venture Contract was concluded on November 10, 1984 in Beijing for the duration of 25 years, in the presence of the German Chancellor Helmut Kohl and the Secretary of the CCP and Head of the State Zhang Ziyang, between the following partners:

- Volkswagen AG (VW) 50\%,

- Shanghai Tractor and Automobile Corporation (STAC) 25\%

- Bank of China (BOC) $15 \%$ and

- China National Automotive Industry Corporation (CNAIC) 10\%.

The Joint Venture Contract contained about 500 pages including the following Appendices:

- Articles of Association,

- Technology Transfer Agreement,

- Time Schedule,

- Contributions in Kind,

- Price Fixation,

- Organizational Structure,

- Scope of Responsibility,

- Local Content Development Program,

- Lay-out and External Infrastructure,

- Feasibility Report,

- The Content of Essential Provisions of Employment Contracts for Expatriates, and

- Housing for Expatriates.

These Appendices constituted an integral part of the contract.

The joint venture under the name Shanghai-Volkswagen (SVW) started the assembly of Santana and the production of engines in 1985. At that time started also the management

26 Zhao (2010) 100.

27 Tangemann (2014). 
of the joint venture. The joint venture contract regulated the management of ShanghaiVolkswagen in the following way:

- the highest organ of the company was the Board of directors $(\mathrm{BoD})$ consisting of ten members, five of which, including the First Vice Chairman, were appointed by VWAG, three by STAC, including the Chairman, one by BOC to be the Second Vice Chairman, and one by SNAIC; the presence of the representatives of the trade union was compulsory though they did not have voting right,

- the board of directors had especially the following tasks:

$=$ The appointment and revocation of the members of the Executive Committee (EXCOM).

$=$ The establishment of general policy/

$=$ The establishment of general plans for the realization of the general policy.

$=$ The establishment of organizational structure

$=$ The establishment of by-laws

$=$ The establishment of product program

$=$ The establishment of investment program

$=$ The establishment of personnel plan. The approval of budgets and of annual reports as well as of the balance sheet, and profit and loss statements as well as

$=$ 'all other activities the Board may deem suitable'.

A unanimous decision was required in many of these cases.

In first stage of its activities, the EXCOM consisted of four members: Managing Director, appointed by STAC, Deputy Managing Director, appointed by VWAG and responsible for finances, purchase and sales, Technical Director, appointed by VWAG, and a Director of Human Resources who was appointed by STAC. The EXCOM was responsible

- to prepare the meetings of the BOD

- to carry out the resolutions and instructions of the BOD the BOD.

- to organize and direct the daily business of the company under the - supervision of

The by-laws of the company stipulated in detail the powers of the EXCOM.

\section{MANAGEMENT OF JOINT VENTURES AND WHOLLY FOREIGN-OWNED COMPANIES}

In China, the management of joint ventures and even of wholly foreign-owned companies requires Chinese management practices which are largely different from the western management styles. It is still highly influenced by Confucianism which is the leading factor in business practices in China.

When managing a joint venture or a wholly foreign-owned company in China, the foreign manager must take several issues into account which are, in general, different from their understanding when managing a company in western countries. Such issues are, also according to the Author's experience:

- conflict of interests

- privacy

- intellectual property rights

- management of personnel

- guanxi

- saving 'Face'

- legality and morality 
- contract and trust, and

- the concept of $y i$

The concept of conflict of interests was not known as a concept in traditional business culture in China because it was quite common for people to do business with their friends and relatives first. When managing a joint venture or a wholly foreign-owned company in China, one must be very careful in the assessment of conflict of interest for not every conflict of interest will be - in western sense - harmful for the company. ${ }^{28}$

The concept of privacy is missing in traditional Chinese culture; there is even no direct translation in Chinese for the English word 'privacy'! Therefore, it will be self-understood that employees may know, e.g., each other's salaries. ${ }^{29}$

Intellectual property right is still a hot issue in China, though this problem is by no means a recent one. Already in the early period of the Qing Dynasty (1644-1912), when the Italian Jesuit missionary Matteo Ricci gave some precious clocks to the emperor Qianlong (1735-1796) as presents, the emperor ordered his experts to dissemble and copy them. The clocks were to be produced within a few days, in the same quality as the presents given by Matteo Ricci under the menace of death penalty in case of failure! Thus, copying the best things was always worth imitation.

In my experience too, Chinese employees prefer clearly defined tasks and are reluctant to acceptjobs that involve any uncertainty. However, many foreign managers do not understand such an attitude of Chinese employees and complain that the Chinese subordinates always ask for detailed instructions, unwilling to act at their own discretion. Refusing or even showing reluctance in carrying out orders from one's superior is viewed as disobedience and considered disgraceful. Therefore, due to the love for harmony in Chinese culture, open dissent should be avoided. Collectivism also had the effect that the Chinese tend not to take personal responsibility. The Chinese do not like formal rule, instead they do prefer precise orders. ${ }^{30}$ Thus, foreign managers must be careful in dealing with Chinese personnel: they must be very precise in giving orders avoiding, at the same time, to humiliate them because then they loose their 'Face' - which is considered disastrous!

Guanxi is a special Chinese notion. It is composed by the words 'guan' meaning door and 'xi' meaning a 'department within an organization'. In the daily life, it mostly means 'personal connection' to be used at the right time and in the right place. The circle of persons with guanxi might be very large. The basic circle is one's family but it may include neighbors, schoolmates and other people with tight connection. ${ }^{31}$ Of course, guanxi ties need to be maintained which may be done through wining and dining but also through the exchange of favors and by maintaining mutual respect and earnest friendship without any intention to harm each other. In fact, it has nothing to do anything with the perception western people may have of guanxi such as cronyism, nepotism, bribery, unfairness or corruption. ${ }^{32}$

The person of the leader such as the family father, the boss of a company, the party secretary or the head of the state is of extreme importance in the Chinese society. These persons have traditionally a patriarchal role and must therefore be respected. Since the status of the leader suggests that he shall be a morally superior person in an ideal Confucian

28 Liu (2010) 42.

29 Liu (2010) 20.

30 Fernandez and Underwood (2006) 15.

31 Liu (2010) 35.

32 Graham and Lam (2004) 40. 
world, to criticize the leader is a delicate thing to do, and it is even more difficult for the leader to acknowledge his fault. Therefore in business, people should act properly to avoid losing 'Face' or damaging the 'Face' of the counterpart. One should especially avoid criticizing the leader in public, obliging him to recognize a fault or refuse a requirement. ${ }^{33}$

On the other hand, some actions may enhance one's 'Face' like:

- reaching an agreement or smooth execution of the contract,

- having important people present on the signing ceremonies or other important occasions, or

- delivering favors to others. ${ }^{34}$

Chinese prefer not to go to court when they have controversy. Instead, they prefer to negotiate the disputed issues either among themselves or by the help of a neutral third party. The reason of this attitude is that they have a negative attitude toward law in general and court, in particular, because of the predominance of criminal law in their history. As already mentioned, also lawyers in negotiations are often considered as a burden and therefore they are only asked to join the negotiating team at the final phase of the negotiations.

Regarding the above mentioned Chinese attitude toward law, it is understandable that the contract was not and is neither nowadays an indispensable tool in doing business in China. Rather it is considered as a record or proof for a transaction which might be modified at any time. However, for the Chinese, if you don't trust your partner, you will not be willing to rely on a piece of paper either. If disputes arise from the contract, they should be solved in a friendly way for it is considered as offensive to refer to the contract because the words put on the paper some time ago may not correspond anymore to the actual wishes and intentions of the parties. Therefore, the Chinese do not intend to honor an agreement unconditionally as a primary principle and do not pay only attention to what is agreed upon but they also consider the most sensible solution to the contract.

The most sensible solution to the contract is often considered the way how to amend it when the situation changes. Therefore, many consider the signature of a contract not as the final point of negotiations but the starting point! The question of honoring a contract is especially important and delicate in long term contracts like, e.g., a joint venture contract. Here, it is essential:

- either to foresee renegotiations of the contract in a specified period of time, or

- leave strategically important questions open for renegotiations at an appropriate time, or

- let some persons or bodies to renegotiate the contract at any time.

The concept of $y i$ can be traced back to an ancient ritual of sacrifice. It means righteousness, correctness, justice and properness and is considered as another concept of Confucianism. $Y i$ is not a set of objective rules. It may be affected by rank of hierarchy, closeness in relationship, familial values, or 'Face'. Therefore, Chinese culture is often called particularistic because the term $y i$ is referring to what is right and suggests universal standards, but in reality, it is actually a particularistic term which may be interpreted case by case. In the practice, $y i$ could mean that if the contracting parties are loyal to each other, they will very well observe the correct meaning of $y i$ and respect each other's specific situation. Thus, the Chinese party receiving western technology will first of all try to satisfy the foreign party's position and will not try to abuse his own situation which might be superior due to the domestic environment and, often, the authority's influence. ${ }^{35}$

33 Liu (2010) 67.

34 Worm (1998) 188.

35 Liu (2010) 81-82. 


\section{THE SECOND JOINT VENTURE OF VOLKSWAGEN: FIRST AUTOMOBILE WORKS (FAW)}

In the negotiations on the first joint venture of VWAG the number of the cars to be produced per year was one of the major issues. In fact, the Chinese partners insisted that the joint venture should not produce more than 10,000 to 15,000 cars per year! In the $1980 \mathrm{~s}$, however, China's economic development largely allowed the production of more cars. The main Chinese automotive producer at that time was the FAW in Changchun, Jilin province, the former capital of Manchukuo, a puppet state created by Japan in 1931. This company was established in 1958 for the production of Hong Qi or Red Flag, the imitation of the Soviet product $\check{C} a j k a$ destined for officials only. One of the first general managers of this company was Jiang Zemin, at the time of our negotiations with FAW Secretary General of the CCP. But the Red Flag was an outgoing model and the Chinese officials wanted to replace it by a new model. Therefore, FAW started negotiations with VWAG and wanted to produce Audi 100. For Audi, the subsidiary of VWAG, the mother company conducted the negotiations.

The negotiations for this joint venture started in 1988 and lasted much shorter than the negotiations for Shanghai Volkswagen probably for several reasons: at that time, Chinese negotiators had already more practical experience in negotiating with foreign partners and the will of the central authorities to set up this joint venture was obviously decisive. Therefore, after two years of negotiation the Joint Venture Contract between VWAG and FAW has been signed in 1990 and the production of Jetta and Audi 100 for the Chinese market as well as the engines to be exported to Audi was started in 1991. The production volume was fixed to 150,000 cars per year.

All of the facilities in the first car plant, including the body shop, paint shop and assembly shop came together from the abandoned factory of VWAG's in Westmoreland, USA. FAW-VW started its production with the Jetta and continued later on with the Audi 100. The structure of this joint venture was the same as the one for SVW.

\section{VW GROUP CHINA}

Usually, foreign subsidiaries may be controlled either by the mother company or by a holding company established in the foreign country, especially when the mother company has several subsidiaries in such country. Since the enactment of the Law on Establishment of Holding Companies by Foreign Business Entities (2004), many foreign companies that have several joint ventures or wholly foreign owned companies set up holding companies.

VWAG did the same. By May 2004, it had concentrated its strength in the founding of Volkswagen Group China (VGC), managed by a six-member management team responsible for the areas of sales and marketing, technology, purchasing, personnel and governmental relations as well as finance. VGC's task also includes supervision of the joint ventures and wholly VW owned companies in China.

VGC, including, of course, its subsidiaries, has today 95,000 employees, has built 30 million cars (including the production of cars since 1985 by SAIC and FAW) by now at 30 Chinese production sites now, which have been sold by 5,000 dealers (with 330,000 employees). In 2016 alone, VGC has built about 4 million cars. The operating income of VGC amounted to EUR 774 million in 2009. VGC has 16 subsidiaries with SAIC and FAW, among them the following:

- Volkswagen (China) Investment Company Ltd., Beijing,

- Volkswagen Finance (China) Company Ltd., Beijing, 
- Volkswagen Beijing Center Company Ltd., Beijing,

- Volkswagen FAW Platform Company Ltd. (Powertrain), Changchun,

- FAW-Volkswagen Sales Company Ltd., Changchun,

- Volkswagen FAW Engine (Dalian) Company Ltd., Dalian,

- Volkswagen Transmission (Dalian) Company Ltd., Dalian,

- Volkswagen Transmission (Shanghai) Company Ltd., Shanghai,

- Shanghai Volkswagen Powertrain Company Ltd., Shanghai,

- SAIC-Volkswagen Sales Company Ltd., Shanghai,

- Volkswagen Import Company Ltd., Tianjin,

- SITECH Dongchang Automotive Seating Technology Ltd., Dongchang,

- Volkswagen Hong Kong Ltd., Hong Kong. ${ }^{36}$

Besides, it has 29 production plants in China, including those of FAW-VW (four) and SAIC-VW (eight). These are the following:

- FAW-VW

$=$ Changchun (two plants),

$=$ Chengdu, and

$=$ Foshan,

- SAIC-VW (formally called Shanghai Volkswagen)

$=$ Shanghai (three plants),

= Nanjing,

$=$ Yizheng,

$=$ Ningbo,

$=$ Urumqi, and

= Changsha,

- 17 component plants, which have produced

$=$ components for 3,420 thousand cars and

$=3.270$ thousand engines.

VGC is now exploiting opportunities through strategic partnerships in four key areas:

- ride sharing,

- mobility club,

- car sharing,

- financial leasing, and

- Poc e-commerce. ${ }^{37}$

\section{A NEW JOINT VENTURE WITH ANHUI JINGHUAI AUTOMOBILE CORP., LTD. (JAC)}

VWAG recently launched a new joint venture with JAC for e-mobility holding $50 \%$ of the stock of the joint venture with a term of 25 years. With this project VGC is pursuing the ambitious target for the 'TOGETHER - Strategy 2025' program in China with the objective to build 400,000 e-vehicles in 2025, together with SAIC, FAW and JAC, the first e-vehicle to be built already in 2018 .

36 VW subsidiaries in China (2015) link 16.

37 New opportunities (2016) link 17. 


\section{SHANGHAI VOLKSWAGEN AUTOMOTIVE COMPANY - TODAY}

Recently, SVW changed its name to SAIC-VW. This is an interesting development. At the beginning of the negotiations between VWAG and its Chinese partners, VWAG insisted on the name 'Volkswagen Shanghai' for the joint venture, thus emphasizing the importance of the name of the car manufacturer. However, the Chinese partners resisted claiming that, the joint venture would be in Shanghai and therefore 'Shanghai' was to be mentioned first. Finally, the negotiating team of VWAG could persuade the board of management of VWAG to accept the Chinese point of view arguing that in the name 'Shanghai-Volkswagen' the word 'Shanghai' could be considered as a mere adjective!

In the meantime, also STAC changed its name into Shanghai Automotive Industry Corporation - SAIC. In 2010, the equity holdings was split and the present participation ratio is as follows:

- Shanghai Automotive Industry Corporation (SAIC) 50\%,

- Volkswagen AG 40\%, and

- Volkswagen (China) Investment Co., Ltd. 10\%.

In the meantime the term of the Joint Venture Contract has been extended to another 45 years, now running until 2030.

Being the biggest shareholder of Shanghai-Volkswagen, SAIC recently insisted to change the name of the joint venture into 'SAIC-Volkswagen'. VWAG accepted this proposal.

In April 2005, Škoda officially landed at SVW where they to produce its different models. The production of the first Škoda car, Octavia, started the production in June 2007, other types of Škoda followed.

By October 2009, SVW (now SAIC-VW) had turned out over five million cars in total, becoming the carmaker with the biggest population of cars in China. Its 22,000 employees are now producing the following models:

- Volkswagen:

= Tiguan LWB

$=$ Touran

$=$ Passat New Lingyu

$=$ New Passat

$=$ Lavida (Sedan)

$=$ Grand Lavida

$=$ Cross Polo

$=$ Polo (Hatchback, Cross Polo, Polo GTI)

$=$ Santana Vista

- Škoda:

= Octavia

$=$ Fabia

$=$ Superb

$=$ Yeti, and

$=$ Rapid $^{38}$

In 2016, SAIC-VW produced 1.90 million cars. 


\section{FAW-VOLKSWAGEN - TODAY}

In 1995, FAW, VW AG and Audi decided to integrate Audi to the product line of FAW-VW and in 1996, the first Audi 100 rolled off the line. In the same year the engine shop started running.

In 1997, FAW-Volkswagen Sales Company Ltd. was established as a joint venture between FAW-VW and the FAW Group with equity holdings of 50\% for each. The participation in the company is today as follows:

- FAW Group: $60 \%$

- Volkswagen AG: $20 \%$

- Audi AG: $10 \%$, and

- Volkswagen (China) Investment Co., Ltd.: 10\%.

FAW-VW is actually producing the following models:

- Audi A3 Type 8V

- Audi A4L Type B9

- Audi A6L Type C7

- Audi Q3

- Audi Q5

- Volkswagen Jetta Night,

- Volkswagen Bora Mk. II

- Volkswagen C-Treck

- Volkswagen Golf Mk.VII

- Volkswagen Golf GTI Mk.VII

- Volkswagen Sagitar Mk. II

- Volkswagen Magotan Type B8L, and

- Volkswagen CC Type $35^{39}$

\section{PRESENT SITUATION IN THE CHINESE CAR INDUSTRY}

In 1985 , only about 10,000 passenger cars were sold in China. ${ }^{40}$ In 2016 , VGC sold 3.98 million units (sales of the cars produced in the joint ventures of SAIC and FAW as well as imported cars), i.e., $12.2 \%$ more than in the previous year. Among these cars

-3 million were Volkswagen,

- 591,600 Audi,

- 317,100 Škoda and

- 65,200 Porsche,

In the same year VGC made a profit of USD 5.36 billion (or 5 billion Euro).

Within the VGC, the production is constantly oriented toward the future based crossbrand production strategy. Digitalization, autonomous driving and e-mobility will fundamentally transform the automobile production of VGC. In 2020, VGC plans to produce 400,000 e-cars and 1.5 million in 2025 .

In 2016, 18.68 million new cars were produced in China, more than in the USA where the car production reached 'only' 17.5 million. In this period, VGC produced and sold 3.026 million cars, which represent $16 \%$ of the Chinese market, thus being behind General

39 FAW-VW models (2016) link 19.

40 Unbegrenzter Wachstum (2015) link 20. 
Motors. The latter produced and sold 3.61 million of cars in China, representing $19 \%$ of the Chinese market.

It is noteworthy that, in Beijing alone 1,200 new cars are being registered on average per day. No wonder, as today there are 6,322 companies that produce cars in China's 27 provinces (out of 31 provinces) and since 2002 about $50 \%$ of the sales went to private persons. This development is also remarkable because today there are very high taxes for the admission of new cars - up to 178,000 Euros per car depending, of course, on the acquired model. ${ }^{41}$

Can such an amount of cars be continued to be produced in China? On the one hand yes, because in China, there are still only 30 cars per 1,000 inhabitants while in the USA and in the EU countries there are 400-500 cars per 1,000 inhabitants. On the other hand, there are 684,000 victims per year due to air pollution. Therefore, it is planned that in 10 years China will not issue license plate for fuel and diesel cars at all.

\section{OTHER ACTIVITIES OF VGC}

Besides of producing cars, VGC also supports the arts, culture and sports in China e.g., the Artistic Engagement Program in order to spread cultural activities throughout China. With the 'VGC Music Night', VGC brought together the Shanghai Symphony Orchestra and students from the Shanghai Orchestra Academy with principal musicians from the German Norddeutscher Rundfunk (NDR) Philharmonie Orchester. VGC also supports the China Youth Football Training and is promoting, in general, football in China. In this context it is interesting to note that already in 1992, SVW financed a German football coach for the Chinese national team.

\section{LITERATURE}

Brzezinski, Zbigniew, Strategic Vision - America and the Crisis of Global Power (Basic Books 2012). Chape, William, 'Effective management communication for China' in Selner, Jan (ed), International Management in China - Cross-cultural issues (Rutledge 1998) 169-82.

Fernandez, Juan Antonio and Underwood, Laurie, China Entrepreneur - Voices of Experience from 40 International Business Pioneers (John Wiley \& Sons Asia PTE LTD 2009).

Graham, John L. and Lam, Mark, 'The Chinese Negotiation' in Libeberthal, Kenneth (ed), Harvard Business Review on Doing Business in China (Harvard Business School Press 2004) 32-56.

Liu, Tony Qian, Confucianism and Business Practices in China (China Financial \& Economic Publishing House 2010).

Pickert, Philip, 'Der falsche Prophet' (30 June 2017) Frankfurter Allgemeine Zeitung <http://www. faz.net/aktuell/wirtschaft/wirtschaftspolitik/marx-lag-mit-das-kapital-komplett-daneben15083275.html> accessed 17 November 2017.

von Senger, Harro, Senn, Marcel (eds), Maoism oder Sinomarxismus? Rechtswissenschaftlichsinologische Tagung an der Universität Zürich, 5. und 6. Dezember 2014 (Franz Steiner 2016). Tangemann, Wolfgang, 'Die Eistest endete' (29 November 2014) Wolfsburger Allgemeine Zeitung.

\section{LINKS}

1. China Population - Worldmeters (2017) <www.worldmeters.info.chinapopulation> accessed 15 June, 2017.

2. Shanghai Population (2017) - World Population Review <worldpopulationreview.com. worldcities $>$ accessed 17, June, 2017.

41 Taxes on luxury cars (2016) link 21. 
3. Changchun Population (2017) <http://en.wikipedia.org/wiki/changchun> accessed 12 July 2017.

4. Majority of Chinese live in Cities (2012) <http://www.nytimes.com/2012/01/18/world/asia/ majority-of-chinese-now-live-in-cities.html $>$ accessed 18 June, 2017.

5. Das Volk will wohnen (2014) Frankfurter Allgemeine Zeitung, 24 June $2014<$ http://www.faz.net/ aktuell/feuilleton/mustersiedlung-tianjin-das-chinesische-volk-will-wohnen-13005822.html > accessed 18 June, 2017.

6. Europa fällt zurück, (2015) Frankfurter Allgemeine Zeitung, 19 February $2015<\mathrm{http} / / / \mathrm{www}$. genios.de/presse-archiv/artikel/FAZ/20150219/europa-faellt-zurueck-studie-beschr/ FD2201502194503020.html > accessed 18 June, 2017.

7. China Daily (2017) <www.chinadaily.com/cn> accessed June 19, 2017.

8. FDI from China (2016) <www.reuters.com/.../us-china-economy-investment-idUSKBN14FOR7R> accessed 21 June 2017.

9. Better than barbarians (2016) The Economist 14 January $2016<$ https://www.economist.com/ news/business/21688389-rich-world-firms-are-warming-idea-being-chinese-owned-betterbarbarians> accessed June 19, 2017.

10. FDI to China (2005) Zhang, Kevin Honglin 'Why does so much FDI from Hong Kong and Taiwan go to Mainland China?' (2005) 3 China Economic Revue 293-307 <https://www. economist.com/news/business/21688389-rich-world-firms-are-warming-idea-being-chineseowned-better-barbarians> accessed 29 June 2017.

11. Chinas grosser Sprung (2015) Frankfurter Allgmeine Zeitung, 3 December 2015 accessed 29 June 2017.

12. Die Weltwährung (2016) Frankfurter Allgemeine Zeitung 20 December $2016<\mathrm{http} / /$ www.faz.net/ aktuell/wirtschaft/die-weltwaehrung-der-dollar-hat-globale-bedeutung-14583059.html $>$ accessed 29 June 2017.

13. Der Yuan etabliert sich auf Kosten des Euro (2015) Frankfurter Allgemeine Zeitung, 2 December 2015<https://econpapers.repec.org/article/eeechieco/v_3a16_3ay_3a2005_3ai_3a3_3ap_3a293-307. htm $>$ accessed 29 June 2017.

14. Der reichste Chinese (2015) Frankfurter Allgemeine Zeitung 15 October $2015<$ http://www.faz. net/aktuell/wirtschaft/menschen-wirtschaft/wang-jianlin-loest-jack-ma-als-reichster-chineseab-13858689.html > accessed 29 June 2017.

15. Chinesen kaufen Technik, Klavierhersteller und Werfte (2016) Frankfurter Allgemeine Zeitung 15 July $2016<$ http://www.genios.de/presse-archiv/artikel/FAZ/20160715/chinesen-kaufen-technikklavierhers/FD2201607154902401.html> accessed 29 June 2017.

16. VW subsidiaries in China (2015) < https://en.wikipedia.org/wiki/Volkswagen> accessed 18 June 2017.

17. New opportunities (2016) <https://www.volkswagenag.com/.../2016/.../2016-12-01\%/20-volks wagen $>$ accessed June 29, 2017.

18. SAIC-VW models (2009) <https://en.m.wikipedia/wiki/saic > accessed 29 June 2017.

19. FAW-VW models (2016) <https://en.m.wikipedia/org/wiki/FAW> accessed 29 June 2017.

20. Im Reich des unbegrenzten Wachstums (2015) Frankfurter Allgemeine Zeitung, April 28, 2015 accessed 29 June 2017.

21. Peking führt über Nacht Steuer auf Luxuswagen ein (2016) Frankfurter Allgemeine Zeitung 2 December $2016<$ http://www.genios.de/presse-archiv/artikel/FAZ/20161202/peking-fuehrt-uebernacht-steuer-au/FD2201612025009063.html> 